\title{
Digitalization of Environmental Tax: the right Tax Policy Reform for Nigeria
}

\author{
${ }^{1}$ Garba I., ${ }^{2}$ Bappayaya B., ${ }^{3}$ Gambo I., ${ }^{4}$ Oluwakayode A.M., ${ }^{5}$ Ayodele A.J. \\ ${ }^{1}$ Department of Accounting, Faculty of Arts and Social Sciences, Gombe State University, \\ Nigeria \\ ${ }^{2}$ School of Basic and Remedial Studies, Gombe State University, Nigeria \\ ${ }^{3}$ Department of Accounting, Abubakar Tatari Ali Polytechnic Bauchi, Nigeria \\ ${ }^{4}$ Department of Accountancy, Faculty of Commerce and Management Studies, university of \\ Kelaniya, Sri Lanka. \\ ${ }^{5}$ Business Education Department, College of Education, Ekiti State Nigeria. \\ Iigarba204@gmail.com, ${ }^{2}$ adekanmbi.john@coeikere.edu.ng, ${ }^{3}$ isahgambo@gmail.com, \\ ${ }^{4}$ adekanmbing88@gmail.com
}

\begin{abstract}
The paper examined different tax policy options that are currently under consideration in the Nigerian economy in supporting tax policy and its administration reforms. Online tax systems are rapidly replacing cumbersome manual-based tax reporting systems which help the ease of doing business in Nigeria by reducing human intervention in the payment and collection of tax and by extension, checks the possibility of connivance of tax officials with fraudulent taxpayers to evade tax. A quantitative method was used in generating data for the studies of which tax consultants and policymakers were randomly selected in the north-east part of the country, and free rider theory was adopted for the research work. It has been recommended that digitalizing environmental taxes is the most efficient tax policy of pursuing many environmental policy goals. There is also the need for consistency and transparency in the policies. Due to the imposition of any environmental tax requires countries to be fair, transparent and keep environmental objectives as priorities.
\end{abstract}

Keywords: Digitalization, Environmental, Tax, Policy, Nigeria, FIRS

\section{Introduction}

It has been well documented that digitalization of environmental taxes is still in its early stage in Nigeria. However, with the coming up of technology in the $21^{\text {st }}$ century many opportunities as to how the environmental tax policy will be used to ease business for the corporate organization and individuals have evolved. The changing business scenario of technological advancement globally has led to having the need of digitalization of taxation. It has been arguably agreed that digitalization of environmental tax has become a child of necessity (Alhasan, 2020).

Digital taxation or e - taxation is the deployment of computer systems and networks in the process of levying and payment of taxes. It involves the application of computer techniques in the process of tax assessment, collection and administration (Amaefule, et al. 2018). It is generally referring to as e-payments and e-filing, it involves the exchange of data through information communication technology 
systems between the taxpayer and tax authorities. Main reasons or motives of coming up with digital taxation are to do away with cumbersome manual service systems and to work with with collaborative, efficient, processing driving and efficient online delivery systems ( Adebowale, 2012, Fowler, 2017).Therefore, the time has come for the Nigeria government to reform its tax system by incorporating digitalization of environmental tax policy in ways that will promote environmental protection and discourage environmental degradation to support our environmental economic goals.

Although it has been generally agreed that additional tax means additional cost to the consumer and producers in the marginalized community where income is low which will not match the increase in cost, especially when the community is depending on those product and service. Price increases can lead to social distress and political instability, and then invariably increase social costs. But is welfare improving to tax bad things high like pollution and good things low.

An environmental tax is defined as: "any compulsory, unrequited payment to the government, in cash or in kind, made to the state by an individual or other legal entity corporate organization". It is referred to as "unrequited' because the state provides nothing in return to the individual or entity making the payment. It is simply payment enforced in terms of its legislation although the state may use the funds raised in taxes to provide goods or services to other units, either individually or collectively, or to the community as a whole. The levied-on tax-bases deemed to be of particular environmental relevance, where the tax bases include energy products, motor vehicles, wastes, measured or estimated emissions, natural resources, etc. (OECD, 2019). The OECD also considers environmental taxation as an instrument for a sustainable economy, that makes use of the tax system to encourage a change of attitude for economic agents to reduce the negative impact that their industrial practices cause to the environment. Whereas (Garba, 2017) understanding on environmental tax is a tax placed on a product that damages the environment,

The objective of the research is to assess different tax policy and to support the Digitalization of the tax system in Nigeria by reforming the tax policy in line with global best practices.

\section{Literature Review}

Reform options must be assessed against working lessons from working with resources - constrained tax administration in developing economies: the need for the rule to be straightforward in their application and the need for transparency (Collin, et al., (2019). Developing countries now recognize the need for global compliance on tax matters, due to presence of innovative approaches on tax management not only by tax authority but also by taxpayers in the form of e-tax payment (Jerkovic,2018). The governments have realized that tax laws which were largely drafted in the $18^{\text {th }}$ to $20^{\text {th }}$ century can no longer meet the $21^{\text {st }}$ digitalization era of very high technology, which is not in line with International Financial Reporting Standard (IFRS). 
With digitalization and e-governance which is gaining ground in both developed and developing countries, tax regulatory bodies in these countries are also warming up on joining the train to expand their tax base. It has been noted by Shireen (2020), that with the coming up of advance technologies and analytical tools, those are being put improve professionalization of the tax collector and mechanism and also the authority to remain effectives and relevant in the system. Simeon et al. (2017), assert that with the coming up of digital transformation, it will help tax administrators and the government with the following primary areas.
i. Transparency
ii. Taxpayer centric solutions
iii. Connected tax to stakeholders
iv. Data driving decision and automated processes

It has been noted that with transparency initiatives the taxpayer will have a confidence in the administration of the taxes are being collected and thus my pave the way for voluntary compliance through e- payment. Because taxpayer will expect timely, accurate and reliable service through digitalization of the tax system because it ensures the safety and secured taxpayers data (Earnest, 2015). Furthermore, with the amendment of Company and Allied Matters Act (CAMA) 2020, digitalization of tax payment system will bring a deeper and clear understanding of citizens, bringing them to voluntarily declare their income and pay taxes which will be making the payment work online and online interactions hitherto achievement of global financial integrity.

According to ICAEW (2016), tax authorities around the world have been busy over the last decade with the process called "channel shifting". This entails moving away from face-to-face interaction with taxpayer postal contact to channels that are digitalized to improve cost- cutting and compliance.

Empirically, Raphel, et al. (2020), examined tax knowledge, complexity and compliance base on digitalization of taxpayers' views so as to uncover the reasons for noncompliance at Akwalbom State. A survey research design was used to obtain data for analysis with the aid of thematic statistical techniques. The results revealed that taxpayers have inadequate technical knowledge and perceive the tax system as complex and therefore contributing to the noncompliance behaviour of taxpayers. Fanea-Ivanovici 2019), conducted a study to examine the impact of digitalization on fighting corruption and tax compliance in Romania. The study relies on time series data and employed descriptive statistics to achieve its objectives. The empirical result obtained revealed a positive relationship between digitalization and tax compliance in Romania. Digitalization leads to the increase of the level of tax compliance because entrepreneurs will feel more confident responsible and, they will decide to better comply.

The concept of e- taxation in Nigeria, as noted, is still a new approach in Nigeria particularly concerning the environmental issues. The introduction of e-taxation was champion by the team of International Monetary Fund (IMF) Fiscal affair division in $2004-2006$ which recommended Nigeria the implementation of the Integrated Tax Administration System (ITAS) (Okauru, 2012, Newman and Eghosa, 2019). In 
December 2010, the Federal Government of Nigeria was given approval to Federal Inland Revenue Service (FIRS) by the Federal Executive Council to procure, install and implement the ITAS (Usman, 2013). The ITAS is aimed at re-engineering and automating the FIRS tax administration process as well as the procurement, installation and deployment of the standard Integrated Government Tax Administration Solution (IGTAS) and hardware infrastructure (Usman,2013). In 2015 the FIRS partnered with the Nigerian Interbank Settlement System (NIBSS) to provide the electronic payment of taxes in Nigeria. This is an automation of all tax processes from tax registration, assessment and filing of returns to payments of taxes. The motives were to adopt an electronic system to make it easier to pay taxes online in all the cities across the country (Abdulrazaq, 2015, Newman and Eghosa, 2019). By reducing human intervention in the payment and collection of tax and by extension, checks the possibility of connivance of tax officials with fraudulent taxpayers to evade tax. Also, with the e- tax collaboration between FIRS and the state revenue boards will be easier and more effective with the help of Tax Identification Number (TIN). Thus, it is easier to develop an authentic tax administration data base and share information amongst tax administrators (Umenweke, and Ifediora, 2016).

Concept of tax digitalization is a tool of tax administration and enforcement, but it was given a special status due to the important role it plays for simplifying tax administration and compliance processes, tax digitalization improves efficiency and transparency in tax administration, reduces tax fraud and corruption, and increases voluntary tax compliance. With the amendment of The Finance Act which came into effect from $13^{\text {th }}$ January 2020, the concept of "Significant Economic Presence" (SEP) has introduced as a new basis for taxation of digital and online transactions by non-residence companies (2020).

Rouse (2017), as cited in Alhasan (2020), defined digitization as the process of converting information into a digital (computer readable) format. Whereas, according to ICAEW (2019), tax digitalization is more than just converting paper forms into PDFs, and uploads on a government website, but rather tax digitalization involves checking how taxpayers complete their filings, what is taxed, and how the authority can leverage powerful data pipelines to complete and audit taxes without a filing is being made. Tax digitalization can also be used to identify non-compliant taxpayers for targeted audits; it reduces the rate of false positives, so that compliant taxpayers are less frequently subject to the cost and inconvenience of a tax audit. Tax digitalization improves taxpayers' service by making the compliance process easier, helpful customized advice and greater real-time transparency over tax affairs. Digitalization can aid in reducing tax avoidance and evasion, by providing additional tools for analysing tax data and catching omissions.

Juswanto and Simms, (2017), are of the view that digitization of tax administration should create the foundation for further tax system reforms. Without building a strong tax administration, information system and competent and honest tax officials, the tax reform will not be possible. Vuković (2019) and Deloitte (2017), identified six level of tax administration digitalization: (i) E-filling (use of standardized electronic form for filing tax returns through the FIRS ITAS online, it 
is one of the innovative aspects of e- tax services. Further, it is a mandatory requirement of Nigeria tax law to file tax returns as taxpayer can upload relevant documents and file taxpayer's tax returns electrically), (ii) E-registration (for registration of new taxpayer with FIRS for the various taxes, with this service taxpayer does not need to visit any tax office to register for tax purposes. All the need to do is to visit the FIRS website and register), (iii). E-stamp duty (for payment of stamp duty), (iv) E-tax payment (for payment of all taxes belonging to Federal Government through following the platform Nigeria Inter-Bank Settlement (NIBSS) Remita and Inter switch), (v). E-Receipt (for receiving and verifying e-receipt generated for tax paid through the new e-tax payment, with this instant notification will be received acknowledgment of taxpayer's tax payment). (vi) Electronic tax clearance certificate (e-TCC): this platform enables taxpayer to apply for tax clearance certificate receiving and verifying the authenticity of their e-TCC.

Moreover, concerning the issues of Environmental policy and pollution control in Nigeria, Progress towards bringing about a cleaner environment has relied on a philosophy of pollution control. This has involved sometimes involved costly measures and controversial political decisions. As a result, developing countries, poor communities and financially constrained enterprises have often argued that the environment is an expensive luxury that diverts resources from more productive uses. This perspective is giving way to a new paradigm stating that neglecting the environment can impose high economic and even financial costs, while many environmental benefits can in fact be achieved at low cost (World Bank, 1998). However, most developing countries have long established laws and formal governmental structures to address their serious environmental problems, but few have been successful in alleviating those problems (Bey, 2012).

Regulations are the most common approach to environmental problems. Standards, bans, permits and quotas are often favoured by policymakers because they promise certainty of outcome without costly monitoring and enforcement, however this promise may not be realized. However, experience from Nigerian environmental policies and implementation has shown that the traditional Command- And-Control System (CAC) to pollution abatement had not produced the desired result both economic and environmental wise. Hence there is he need to examine the potential of mixed environmental policies involving the use of market-based instruments such as environmental taxation to complement the traditional command-and-control system in achieving economic efficiency in the use of the resource.

The policymakers to be better informed on everything they need to do to make the market -based instrument work otherwise they have little to show for their efforts in terms of a cleaner environment. Hence, policy makers need to understand the extent to which resource and environmental conditions impinge upon macroeconomic performance. Bad resource policies can actually deteriorate long-run economic growth by dissipating the wealth inherent in natural resource stocks. Excessive pollution levels damage not only economic assets but human health as well. Excessive levels of pollution-linked illness result in loss of productivity, and excess levels of mortality imply substantial welfare loss. 
The effectiveness of environmental taxation will help in regulating some targeted substances causing environmental pollution in Nigeria and over all global warming (Odinkonigbo, 2012). Taxes might be called effective if they do what they are supposed to do. In theory, environmental taxation should attempt to improve the market efficiency of the environmental goods and services by imposing a price on such goods equal to the marginal costs of their use (marginal environmental damage costs). If authorities manage to calculate these costs, environmental taxation is inherently effective, provided that no other major imperfections distort the relevant markets. Good knowledge of marginal environmental damage costs is an exception. However. Only one example is known where authorities explicitly base the tax rate on an estimate of these costs (OECD, 2017).

The argument for environmental taxes is that, if a product or activity is made more expensive, people will respectively buy or do less of it. If the activity is associated with excessive environmental damage, this will reduce the environmental damage. It is obviously desirable to evaluate the extent to which this argument holds up in practice - the extent to which environmental taxes really lead to environmental improvement. Evaluations of environmental taxes following their implementation are desirable not only to see how effective they have been in environmental terms, but also to learn lessons about how best to introduce them and to communicate their impact and value to policy makers (EEA 2012).

\section{Theoretical underpinning: The Free Rider Theory}

The theoretical perspective of this study is grounded in the idea of free rider problem which was first recognized in the work of Plato in his famous book of the republic, where he argues that one can only obey rules, if it is not possible for him to escape the sanctions of violations. For example, the free rider problem occurs in situations in which a person derives a "positive externality" from the action of another that is, a benefit that he did not pay for. This occurs in a situation where the beneficial effect of an action is "non excludable" meaning that the benefits cannot be withheld from people who had nothing to do with the action.

Even Adam Smith Invisible hand theorem, which promotes self-interest as the main motivator of human action is implying Free Rider Problem. But the idea of the theory was clearly seen in the work of Pareto in 1935, Pareto said that if all individuals in a society will refrained from doing a certain harmful act in a society, every individual member of the society would derive a certain benefit. But if all members of the society except one continue refraining from doing, the harmful act, the society loss is very insignificant, where the person doing the harmful act makes a personal gain, which is greater than the loss he incurs as a member of the society. The current tax system encourages the depletion of natural resources and the unsustainable degradation of the environment. While at the same time discouraging job creation. Ideally, a shift towards taxing unwanted effects on the desiredone without increasing the total tax burden will use a market mechanism to influence and reward more sustainable behaviour without more government regulations.

The Free Rider Theory is the basis or essence of tax administration enforcement, because if all member of a community will voluntarily contribute a certain 
percentage of their income or wealth to the community with the main purpose of providing a certain public good such as good roads, security etc, a free rider having knowing that with or without his contribution, the project will continue, and as a member of the community he will still benefit from the project, he will refrain from contributing. But tax is compulsory, and it is the work of a tax administration to identify a free rider and force him to comply. The theory gave a powerful insight about the motives behind intentional noncompliance.

\section{Methodology}

The research employs a survey design to examine Digitalization of environmental tax as the right tax reform for the Nigerian government. The survey design was deemed appropriate for the research work because a survey research obtain a stronger data representation and accurate approximation. Therefore, a questionnaire was administered in order to collect the necessary data. Moreover, a cross section data was obtained. The data source was from Federal Inland Revenue Service (FIRS). The population of the study was 120 staff of FIRS which was randomly selected, among the middle and senior staff of the agency from north- east Nigeria offices. The questionnaire was structured using the five Likert rated scale which is as follows: Strongly Agree $(\mathrm{SA})=5$, Agree $(\mathrm{A})=4$, Disagree $(\mathrm{D})=3$, Strongly Disagree $(\mathrm{SD})=2$, Not sure $(\mathrm{NS})=1$. The data were analysed using SPSS Version 21. Therefore, the questionnaire was administered in order to collect the necessary data for the study.

Descriptive statistics and simple linear regression were used to analyse the data with $5 \%$ level of significance. Furthermore, Cronbach's Alpha statistics were used to test the reliability of the data collected. The model of the study is stated as follows.

\section{Model Specification}

$$
\begin{aligned}
& Y=f(x) \\
& Y_{I}=\beta_{0}+\beta_{1}+X+\varepsilon_{i}
\end{aligned}
$$

Where:

$\mathrm{Y}=$ Dependent Variable: Digitilisation of Environmental Taxation

$\mathrm{X}=$ Independent Variable: Tax policy Reform

Model Specification

$\mathrm{DET}=\beta_{0}+\beta_{1} T P+\varepsilon_{t,}$

Where:

DET $=$ Digitilisation of Environmental Tax

$\mathrm{TP}=\mathrm{Tax}$ Policy

$\beta_{0}=$ Regression Intercept of TP which is constant

$\beta_{1}=$ Coefficient of explanatory variables DET and 
$\varepsilon_{1}=$ Random error term

$\mathrm{i}=$ Cross sectional

\section{Data Analysis and Discussion of Result}

\section{Data Presentation}

The data collected has been presented as follows.

Table I: Digitalization of environmental tax: the right tax policy reform for Nigeria

\begin{tabular}{|c|c|c|c|c|c|c|}
\hline \multirow{2}{*}{$\begin{array}{l}\mathrm{S} . \\
\mathrm{N}\end{array}$} & Statement & SA & A & $\mathrm{D}$ & SD & NS \\
\hline & Ranking & 5 & 4 & 3 & 2 & 1 \\
\hline \multirow[t]{2}{*}{1} & Digitalization of environmental tax & 80 & 40 & 0 & 0 & 0 \\
\hline & is good innovation for Nigeria & $75 \%$ & $25 \%$ & $0 \%$ & $0 \%$ & $0 \%$ \\
\hline \multirow[t]{2}{*}{2} & Digitalization of environmental tax & 50 & 60 & 0 & 0 & 10 \\
\hline & $\begin{array}{l}\text { is possible with the new } \\
\text { technological advancement in } \\
\text { Nigeria }\end{array}$ & $42 \%$ & $50 \%$ & $0 \%$ & $0 \%$ & $8 \%$ \\
\hline \multirow[t]{2}{*}{3} & A good environmental policy is a & 60 & 50 & 0 & 0 & 10 \\
\hline & good tax policy & $50 \%$ & $42 \%$ & $0 \%$ & $0 \%$ & $8 \%$ \\
\hline \multirow[t]{2}{*}{4} & Environmental tax policy is long & 40 & 75 & 0 & 0 & 5 \\
\hline & $\begin{array}{l}\text { overdue to tackle pollution in } \\
\text { Nigeria }\end{array}$ & $33 \%$ & $63 \%$ & $0 \%$ & $0 \%$ & $4 \%$ \\
\hline \multirow[t]{2}{*}{5} & Government should impose a strong & 80 & 40 & 0 & 0 & 0 \\
\hline & $\begin{array}{l}\text { policy on tax to address } \\
\text { environmental issues }\end{array}$ & $75 \%$ & $25 \%$ & $0 \%$ & $0 \%$ & $0 \%$ \\
\hline \multirow[t]{2}{*}{6} & The Nigeria taxpayer welcome the & 20 & 40 & 0 & 0 & 60 \\
\hline & introduction of environmental tax & $17 \%$ & $33 \%$ & $0 \%$ & $0 \%$ & $50 \%$ \\
\hline \multirow[t]{2}{*}{7} & Environmental taxation will correct & 40 & 55 & 5 & 0 & 20 \\
\hline & major ecological problem & $33 \%$ & $49 \%$ & $4 \%$ & $0 \%$ & $17 \%$ \\
\hline \multirow[t]{2}{*}{8} & Nigeria taxpayer is willing to & 50 & 60 & 0 & 0 & 10 \\
\hline & $\begin{array}{l}\text { support environmental taxation } \\
\text { laws initiatives }\end{array}$ & $42 \%$ & $50 \%$ & $0 \%$ & $0 \%$ & $8 \%$ \\
\hline
\end{tabular}

Source: Field survey 2019

From Table I Digitalization of environmental tax is a good innovation for Nigeria, Digitalization is possible with the new technological advancement in Nigeria, A good environmental policy is a good tax policy, environmental tax policy is long overdue to tackle pollution in Nigeria, Government should impose a strong policy reform on tax to address environmental issues, the Nigerian taxpayers welcome the introduction of environmental tax, environmental taxation will correct the major ecological problem, Nigeria taxpayers is willing to support environmental taxation laws initiatives. It has been observed that the majority of the respondents in each of the statement choosen strongly agree (SA) and Agree (A) which is far greater than 
the respondents who choose Disagree (D), Strongly Disagree (SD) and, Not sure (NS).

\section{Reliability Test}

The Cronbach's Alpha Statistics computed was presented as follows:

\section{Table II: Reliability Test}

\begin{tabular}{|c|c|c|c|c|c|c|}
\hline $\begin{array}{l}\text { S. } \\
N\end{array}$ & Statement & $\begin{array}{l}\text { Scale } \\
\text { Mean } \\
\text { if Item } \\
\text { Delete } \\
\quad d\end{array}$ & $\begin{array}{l}\text { Scale } \\
\text { Varian } \\
\text { ce if } \\
\text { Item } \\
\text { Delete } \\
\text { d }\end{array}$ & $\begin{array}{l}\text { Corrected } \\
\text { Item } \\
\text { Total } \\
\text { Correlatio } \\
\text { n }\end{array}$ & $\begin{array}{l}\text { Squared } \\
\text { Multiple } \\
\text { Correlatio } \\
\text { n }\end{array}$ & $\begin{array}{l}\text { Cronbach } \\
\text { 's Alpha } \\
\text { if Item is } \\
\text { Deleted }\end{array}$ \\
\hline 1 & $\begin{array}{l}\text { Digitalization of } \\
\text { environmental tax } \\
\text { is good innovation } \\
\text { for Nigeria }\end{array}$ & $\begin{array}{c}22.300 \\
0\end{array}$ & 14.010 & 0.762 & 0.799 & 0.966 \\
\hline 2 & $\begin{array}{l}\text { Digitalization of } \\
\text { environmental tax } \\
\text { is possible with the } \\
\text { new technological } \\
\text { advancement in } \\
\text { Nigeria }\end{array}$ & $\begin{array}{c}22.770 \\
0\end{array}$ & 8.920 & 0.933 & 0.994 & 0.865 \\
\hline 3 & $\begin{array}{l}\text { A good } \\
\text { environmental } \\
\text { policy is a good tax } \\
\text { policy }\end{array}$ & $\begin{array}{c}22.600 \\
4\end{array}$ & 9.471 & 0.983 & 0.997 & 0.884 \\
\hline 4 & $\begin{array}{l}\text { Environmental tax } \\
\text { policy is long } \\
\text { overdue to tackle } \\
\text { pollution in Nigeria }\end{array}$ & 22.675 & 10.930 & 0.954 & 0.965 & 0.882 \\
\hline 5 & $\begin{array}{l}\text { Government should } \\
\text { impose a strong } \\
\text { policy on tax to } \\
\text { address } \\
\text { environmental } \\
\text { issues }\end{array}$ & $\begin{array}{c}22.400 \\
0\end{array}$ & 13.844 & 0.872 & 0.841 & 0.930 \\
\hline 6 & $\begin{array}{l}\text { The Nigeria } \\
\text { taxpayer welcome } \\
\text { the introduction of } \\
\text { environmental tax }\end{array}$ & $\begin{array}{c}22.250 \\
0\end{array}$ & 13.649 & 0.877 & 0.825 & 0.933 \\
\hline 7 & $\begin{array}{l}\text { Environmental } \\
\text { taxation will } \\
\text { correct major } \\
\text { ecological problem }\end{array}$ & $\begin{array}{c}22.650 \\
0\end{array}$ & 13.788 & 0.954 & 0.872 & 0.920 \\
\hline
\end{tabular}




\section{$8 \quad$ Nigeria taxpayer is \\ $22.750 \quad 13.965 \quad 0.874$ \\ 0.862 \\ 0.945 willing to support \\ environmental \\ taxation laws \\ initiatives}

Source: Field survey 2019

From the table it has shown that all the data collected were from the questions was reliable because the statistics are significantly greater than $60 \%$.

\section{Descriptive Statistics}

The descriptive statistics were obtained as shown below.

Table III: Descriptive Statistics

\begin{tabular}{|c|c|c|c|c|c|c|}
\hline S.N & Statement & $N$ & MIN & $M A X$ & MEAN & $S T D$ \\
\hline 1 & $\begin{array}{l}\text { Digitalization of } \\
\text { environmental tax is good } \\
\text { innovation for Nigeria }\end{array}$ & 120 & 4.00 & 5.00 & 4.8500 & 0.4386 \\
\hline 2 & $\begin{array}{l}\text { Digitalization of } \\
\text { environmental tax is possible } \\
\text { with the new technological } \\
\text { advancement in Nigeria }\end{array}$ & 120 & 1.00 & 5.00 & 4.2500 & 1.1755 \\
\hline 3 & $\begin{array}{l}\text { A good environmental policy } \\
\text { is a good tax policy }\end{array}$ & 120 & 1.00 & 5.00 & 4.2000 & 0.8124 \\
\hline 4 & $\begin{array}{l}\text { Environmental tax policy is } \\
\text { long overdue to tackle } \\
\text { pollution in Nigeria }\end{array}$ & 120 & 2.00 & 5.00 & 4.6000 & 0.4651 \\
\hline 5 & $\begin{array}{l}\text { Government should impose a } \\
\text { strong policy on tax to } \\
\text { address environmental issues }\end{array}$ & 120 & 4.00 & 5.00 & 4.7000 & 0.4965 \\
\hline 6 & $\begin{array}{l}\text { The Nigeria taxpayer } \\
\text { welcome the introduction of } \\
\text { environmental tax }\end{array}$ & 120 & 4.00 & 5.00 & 4.5000 & 0.4340 \\
\hline 7 & $\begin{array}{l}\text { Environmental taxation will } \\
\text { correct major ecological } \\
\text { problem }\end{array}$ & 120 & 4.00 & 5.00 & 4.4500 & 0.8148 \\
\hline 8 & $\begin{array}{l}\text { Nigeria taxpayer is willing to } \\
\text { support environmental } \\
\text { taxation laws initiatives }\end{array}$ & 120 & 4.00 & 5.00 & 4.2300 & 0.4650 \\
\hline
\end{tabular}

Source: Field survey 2019

The table has shown the responses of the respondents, which indicates the Minimum, Maximum, Mean and Standard Deviation of each response. It has been observed that the deviation from the mean was not high. 


\section{Regression Analysis}

Table IV: Summary of the Analysis

\begin{tabular}{lllllll}
\hline Variable & $\begin{array}{l}\text { Beta } \\
(\boldsymbol{\beta})\end{array}$ & P-Value & Remarks & DW & $\mathrm{R}^{2}$ & $\begin{array}{l}\text { Adjusted } \\
\mathrm{R}^{2}\end{array}$ \\
DET & -0.552 & 0.000 & Significant & 2.366 & 0.807 & 0.804 \\
\hline
\end{tabular}

Source: Computed by the Researcher 2019

Dependent variable: DET from the table Digitalization of Environmental Taxation (DET) although has a negative but significant impact on tax policy (TP) in Nigeria resulted to $55.2 \%$ and the DW statistics of 2.366 indicates there was no first order autocorrelation in the model. $\mathrm{R}^{2}$ which is the coefficient determination shows that $80.7 \%$ of changes in TP was caused by the influence of DET.

\section{Discussion on the Findings}

Based on the results obtained from the questionnaire administered, Legislatures should reform the Nigerian tax laws through digitalization as it will ease the doing business in the country, considering the rise in the health issues and general environmental complaint by the host community. It has also been found out that etransaction has been on the increase, which is assumed to help the economy positively. It has been noted that the taxpayer needs to be educated well with regard to e-transactions in the country.

\section{Conclusion and Recommendations}

Although Nigeria imposes regulations on the polluting industries such as the oil industry, cement industry and so on, it does not properly enforce them due to a lack of independent oversight by environmental agencies. The Federal government is a partner in these industries as well as the party responsible for enforcing environmental laws and standards (Amnesty, 2014). Therefore, it is not uncommon for a government to be in partnership within an industry that it regulates.

Therefore, there is the urgent need for government interventions through market base instrument approach environmental tax; in particular, to ensure that all the environmental legislation especially the one that relates to cement dust pollution and air pollution is seriously enforced.

It has been recommended that digitalizing environmental taxes are the most efficient tax policy of pursuing many environmental policy goals, so that countries that use them appropriately very well will perform better economically than countries that seek to actualise environmental goals. Further, policy recommendations: Nigerian government should encourage implementing the environmental tax policy as it is an effective mechanism for reducing the environmental pollution. There is also the need for consistency and transparency in the policies. Because the imposition of any environmental tax requires countries to be fair, transparent and keep environmental objectives as priorities. Therefore, the government of Nigeria should consider tax policy reform that will aid e- 
transcations, tax education and including taxation of e-transactions in the tax laws. By doing so the economy would be impacted positively.

\section{References}

Abdulrazaq, A.O (2015). Overview of FIRS Electronic Tax Filing and Online Payment of Taxes. Available at http://www.linkeden.com/pulse.overview-firs-electronic-tax-fillingsonline-payment-taxes;Nigeria Tax update

Adebowale, H.I (2012). E- Taxation in Nigeria Issues and Challenges and Prospects. International Companies and Commercial Law Review, 2012

Alhasan, U. (2020). An Empirical Assessment of the Impact of Tax Digitalization of Tax Laws, Tax Administration, and Public Goods Provision on Property Tax Compliance in Kaduna State, Nigeria

Ofurum, C.N., Amaefule, L.I., Okonya, B.E. and Amaefule, H.C., (2018). Impact of Etaxation on Nigeria's revenue and economic growth: A pre-post analysis. International Journal of Finance and Accounting, 7(2), pp.19-26.

Amnesty, (2014). Shell claim on Niger Delta clean up: Premium time's newspaper march 2014.

Berg, B.J (1998). Qualitative research methods for the social science. Allyn and Bacon USA Publishers

Bey, C. (2012). Changing economies of scale - synergies between implementation of ecological tax reform and development of industrial ecosystems. Business Strategy and Environment Journal, 10(4)pp.383- 393.

CAMA (2020) Companies and allied matters act as amended (2020)

Colin, C,. Jonathan, L.P, Jan, L. \&Marijin, V. (2019) International Tax Reform, Digitalization and Developing Economies, Discussion paper 16(2), 2019

Earnest, E. Ogheneovo., F. \& Ayodeji, J. (2015), Design and development of an e-Taxation System. European Science Journal. 2(11), pp.53-60

Eghosa, P. and Newman, C. (2019). The Efficacy of e- taxation as a Strategic Tool for National Economic Development. National Journal of Banking and Finance

Onuiri Ernest, E., Fikayo, F., Ogheneovo, E. and Ayodeji, J.,(2015) Design and Development Of An E-Taxation System. European Science Journal. 2(11),Pp. 53-60

EEA (2012). Environmental taxes: implementation and environmental effectiveness. Environmental issues series 11EEA, Luxembourg; (Online), (Retrieved August 26,2013). http://www.geota.pt/rfa/docs/gt.

Fanea-Ivanovici, M., Mus setescu, R, Pană, M., and Voicu, C., (2019) "Fighting Corruption and Enhancing Tax Compliance through Digitization: Achieving Sustainable Development in Romania." www.mpdi.com/journal/sustainablity.

Fowler, T., (2017) "Property tax is an untapped goldmine in Nigeria" Guarding Newspaper, 31st July, 2017.

Garba, I., (2017). Environmental cost disclosure practices by oil and gas industries. International Journal of Accounting and Finance, 3(2), pp. 23-38. 
Institute of Chartered Accountants of England and Wales ICAEW (2016). Digitalization of Tax International Perspectives. Working Paper

Jerković, E., (2018). Decentralization of Financing of Self-Government Units in the Republic of Croatia. European Scientific Journal. Special edition, pp.105-118.

Juswanto, W. and Simms, R., (2017). Fair Taxation in the Digital Economy.

Newman, U. R \& Eghosa, O.E (2019) Electronic Taxation in Nigeria: Challenges and Prospects. International Company and Commercial Law Review, 2019

Bisong, D.B. and Oguwmike, J.H.C., (2019). Electronic Governance and Fraud Detection in Internally Generated Revenue in Cross River State, Nigeria. International Company and Commercial Law Review

Odinkonigbo, J. J, (2012) Nigerian Judicial Review, 10(2), pp.95-100

Organisation for Economic Co-operation and Development (OECD), 2017. Raising tax revenues are key to economic development in Africa countries. OECD website http://www.oecd.org./tax/retrieved on 3.11.2017

Organisation for Economic Co-operation and Development (OECD), 2019. OECD skills outlook 2019: Thriving in a digital world. OECD, Paris, France.

Simeon, E.D., Simeon, E.I. and Roberts, I.A., (2017). Issues and challenges inherent in the Nigerian tax system. American Journal of Management Science and Engineering, 2(4), pp.52-57.

Raphael, S.E, Mfon, S.J \&Patrick, B.S (2020). Tax Compliance and Digitilisation of Nigerian Economy: The Empirical Review. American International Journal of Social Science, 9(2), pp.42-55

Rouse,M.,(2017)“Digitalization:Definition.”https://whatis.techtarget.com/definition/digitizat ion

Saldana, J. (2009). The cording manual for qualitative research, Sage Publication, London

Shireen. G.O. (2020). Taxation and Nigerian Economy growth process. Journal of Finance and Accounting, 10(6),pp.93-102

Taylor, S, \& Bogdan, D. (1984). Introduction to research methods. Willy, New York

Usman, U.Y (2013), The ITAS Solution Gathered Momentum, Gauge (quarterly publication of the Federal Inland Revenue Service) (January - March 2013) P.8

Umenweke, M.N \& Ifediora, E. S (2016) The law and practice of e-taxation in Nigeria: The Gain and Challenges. Journal of International law and Jurisprudence, 3(5), pp.101-102

World Bank (1998): Pollution Prevention and Abatement Handbook, Toward Cleaner Production, The World Bank Group in Collaboration with UNEP and UNIDO, IBRD/The World Bank, Washington DC, USA. 